\title{
Immunomagnetic Recovery of Chlamydia trachomatis from Urine with Subsequent Colorimetric DNA Detection
}

\author{
Anders Hedrum, ${ }^{1}$ Joakim Lundeberg, ${ }^{1}$ Carl Påhlson, ${ }^{2}$ and Mathias Uhlén ${ }^{1}$
}

\author{
${ }^{1}$ Department of Biochemistry, and Biotechnology Royal Institute of Technology, S-100 44 Stockholm, Sweden; ${ }^{2}$ Department of \\ Clinical Microbiology, Akademiska Hospital, S-751 22 Uppsala, Sweden
}

\begin{abstract}
There is need for integrated systems that provide rapid and sensitive diagnosis of Chlamydia trachomatis. Here we describe for the first time that specific antibodies to a C. trachomatis surface protein can be used for magnetic recovery of bacteria directly from crude urine samples. The combination of immunomagnetic separation (IMS), where the bacterial cells are both purified and concentrated, with a colorimetric PCR assay makes the method sensitive and suitable for routine clinical screening in microtiter format. No filtrations, centrifugations, extractions, or electrophoretic techniques are required throughout the whole procedure. Using magnetic beads as the solid phase, the colorimetric detection of immobilized amplified nucleic acids (DIANA) also allow direct DNA sequencing of positive samples for more detailed analysis. Of the 27 urine samples analyzed, eight were found to be positive using this method. Only five out of these eight were determined to be positive by cell culture.
\end{abstract}

hlamydiae are obligate intracellular bacteria that are unable to synthesize high-energy compounds (ATP, GTP) essential for metabolism and respiration. ${ }^{(1)}$ The Chlamydia genus can be divided into three species: Chlamydia trachomatis with 15 serovars, C. psittaci, and the recently described $C$. pneumoniae. ${ }^{(2)} C$. trachomatis is known to cause a variety of symptomatic and asymptomatic infections in the lower genital tracts of both men and women.

Because chlamydial infection is the most common sexually transmitted disease (STD), it is of great importance to have a rapid and sensitive method, facilitating large-scale screening to achieve a quick and reliable diagnosis for early treatment. Today, the most common method for detecting $C$. trachomatis is based on isolation of the pathogen by cell culture, a technique that is time consuming, cumbersome, and dependent on viable Chlamydiae present in the sample. Recently, alternative techniques relying on antigen detection, such as direct fluorescent antibody (DFA) testing and enzyme immunoassay (EIA), have been developed. The cell culture technique has been compared to the antigen detection techniques in a number of studies showing varying results in sensitivity and specificity. ${ }^{(3-10)}$

The PCR has become a valuable tool for detection and characterication of pathogens, including bacteria, viruses, and parasites. ${ }^{(11)}$ In vitro amplification of pathogen-derived DNA from clinical specimens, such as blood, urine, or feces, requires an initial sample preparation to avoid the presence of polymerase inhibitors and to prepare a sample volume suitable for PCR. In addition, simple detection systems without the need for electrophoresis or radioactive labeling are essential to make the assay suitable for large-scale screening. In this paper, a general and integrated approach for $C$. trachomatis detection from urine samples is presented. It combines PCR with an initial enrichment of target Chlamydiae elementary bodies (EB) using immunomagnetic separation (IMS). ${ }^{(12)}$ The colorimetric detection of amplified target DNA utilizes the detection of immobilized amplified nucleic acids (DIANA) as described before. ${ }^{(13,14)}$ This colorimetric analysis is performed in a standard 96-well format, facilitating rapid screening.

\section{MATERIALS AND METHODS Clinical Samples}

Urine samples were obtained from Akademiska Hospital (Uppsala, Sweden). A total of 27 samples, from symptomatic men attending a STD clinic, were collected and analyzed. Samples were collected as both first cast urine and a subsequent swab for culture. The urine was transported in $10-\mathrm{ml}$ tubes at ambient temperatures. If not analyzed at once, the urine was stored at $+4^{\circ} \mathrm{C}$ for no longer than $48 \mathrm{hr}$. No pretreatment of the urine was necessary. Pipetting of urine was performed using a Gilson MICROMAN displacement pipette (Gilson Inc., Massachusetts).

\section{Cultivation and IF}

The isolation technique for C. trachomatis using McCoy cells was performed as 
described by Ripa et al. ${ }^{(15)}$ Compared to earlier techniques involving McCoy cells, the cells were not pretreated before infection. Cycloheximide was added to the culture medium after infection. After incubation, the cells were stained with a fluorescein-labeled monoclonal antibody, Micro Trak C. trachomatis Confirmation test (Syva Co., California), and the number of inclusion forming units (IFU) was determined by using fluorescence microscopy.

\section{Bacterial Strain}

C. trachomatis serovar L2 was kindly supplied by Dr. Håkan Gnarpe (Gävle Hospital, Sweden) and was used as positive control.

\section{Oligonucleotide Synthesis}

Two sets of PCR oligonucleotides, RIT 23-RIT $26^{(14)}$ and one sequencing oligonucleotide, RIT $43,{ }^{(14)}$ were synthesized by phosphoramidite chemistry on an automated DNA synthesis machine (Gene Assembler Plus, Pharmacia LKB, Uppsala, Sweden) according to the manufacturer's manual. The four PCR primers are complementary to the DNA sequence encoding the cysteine-rich protein $(\mathrm{CrP})$ found in all known $C$. trachomatis serovars. ${ }^{(16)}$ This sequence was chosen as a target region for amplification because it had earlier been shown to represent chlamydia accurately in clinical samples. ${ }^{(14)}$

\section{Immunomagnetic Separation (IMS)}

A polyclonal sera (40 $\mu \mathrm{l} / \mathrm{sample})$, rabbit anti-Chlamydia (Syva MicroTrak Chlamydia EIA, Syva Co., CA), directed toward chlamydial lipopolysaccharides (LPS) was used. It was coupled to precoated magnetic beads, Dynabeads $\mathrm{M}-280$ sheep anti-rabbit IgG (Dynal AS, Oslo, Norway), in a direct technique according to the supplier's recommendation. The amount of precoated beads used in the IMS is $200 \mu \mathrm{g}(20 \mu \mathrm{l}) / \mathrm{sample}$. The beadantibody complex was subsequently incubated end over end with $2 \mathrm{ml}$ of urine sample for $45 \mathrm{~min}$ at $+4^{\circ} \mathrm{C}$. By applying a magnet (Dynal Magnet Particle Concentrator, Dynal AS, Oslo, Norway) to the wall of the tube, the beads with immunocaptured target (EB) are drawn to the wall of the tube and can thus be separated. The beads with captured EB were washed once in a $10 \mathrm{~mm}$ Tris- $\mathrm{HCl}(\mathrm{pH}$ 8.3) buffer and resuspended in $10 \mu$ l of the same buffer. The resuspended beads were taken directly to PCR. The clinical samples were tested in duplicate.

\section{In Vitro Amplification}

The in vitro amplification of C. trachomatis DNA was performed using a Techne Programmable Dri-Block PHC-2 (Techne, Cambridge, UK) and run in a nested procedure. The first amplification step was run with the outer primer pair RIT 23 and RIT 24 for 35 cycles. From the outer amplification, $5 \mu \mathrm{l}$ was transferred to a second amplification step with the inner primer pair RIT 25 and RIT 26 for $30 \mathrm{cy}$ cles, generating the 264-bp inner fragment for positive samples analyzed using $1 \%$ agarose gel electrophoresis (data not shown) and the DIANA system. ${ }^{(13,14)}$ The PCR buffer in both the outer and the inner amplification consisted of $10 \mathrm{~mm}$ Tris- $\mathrm{HCl}$ ( $\mathrm{pH} \mathrm{8.3),} 1.5 \mathrm{~mm} \mathrm{MgCl}_{2}, 50 \mathrm{~mm}$ $\mathrm{KCl}, 0.1 \%$ Tween $20,0.2 \mathrm{~mm}$ dNTPs, 0.2 $\mu \mathrm{M}$ primer, and 1.0 unit of AmpliTaq DNA polymerase (Cetus, Norwalk, Connecticut) to a total volume of $50 \mu \mathrm{l}$. The PCR reaction mixture was covered with a layer of mineral oil (Sigma Chemical Co.). The resuspended beads were added through the mineral oil. The temperature cycle in the amplification program consisted of: denaturation $96^{\circ} \mathrm{C}, 0.5 \mathrm{~min}$; annealing $59^{\circ} \mathrm{C}, 1 \mathrm{~min}$; extension $72^{\circ} \mathrm{C}, 2$ $\min$.

\section{Contamination Precautions}

To avoid contamination, the PCR components were mixed in a separate room before adding the template in a second room. A third room was used for amplification and colorimetric detection. Also, separate pipettes with aerosol-resistant tips (ART20 and ARTXL, Promega, Wisconsin) were used.

\section{Agarose Gel Electrophoresis}

The amplified material $(10 \mu \mathrm{l})$ was separated by $1 \%$ agarose gel electrophoresis, and the presence or absence of a specific 264-bp band was determined after ethidium bromide staining.

\section{Detection of Immobilized Amplified Nucleic Acids (DIANA)}

The solid phase used for analysis in the
DIANA assay consisted of magnetic beads with covalently coupled streptavidin, Dynabeads M-280 Streptavidin (Dynal AS, Oslo, Norway). ${ }^{(17)}$ The magnetic beads, $10 \mu \mathrm{l}(100 \mu \mathrm{g})$ were mixed with $40 \mu$ l of the PCR mixture and $40 \mu \mathrm{l}$ $1 \times$ DIANA buffer $(0.1 \mathrm{M}$ Tris- $\mathrm{HCl}, \mathrm{pH} 7.5$, $0.15 \mathrm{M} \mathrm{NaCl}, 0.1 \%$ Tween 20, $1.0 \mathrm{~mm}$ $\mathrm{MgCl}_{2}$, and $10 \mathrm{~mm} \beta$-mercaptoethanol) in a microtiterplate (Costar, Serocluster Vinyl plate, Cambridge, MA) and incubated for $20 \mathrm{~min}$ at room temperature. The magnetic beads with immobilized amplified DNA were separated by applying a microtiterplate magnet Dynal MPC-96 (Dynal AS, Oslo, Norway) and washed once with $100 \mu$ l of $1 \times$ DIANA buffer. The washed beads were incubated with $50 \mu$ l of LacI- $\beta$-galactosidase fusion protein (Dynal AS, Oslo, Norway) for $20 \mathrm{~min}$ at room temperature. The Dynabeads were subsequently washed four times with $150 \mu \mathrm{l}$ of $1 \times$ DIANA buffer. After the last washing step, the beads were resuspended in $50 \mu \mathrm{l}$ of $1 \times$ DIANA buffer, and $50 \mu$ l of substrate solution ( $\alpha$-nitrophenyl- $\beta$-D-galactoside, ONPG, $1.25 \mathrm{mg} / \mathrm{ml}$ ) was added. After 5 min, $90 \mu$ l of the reaction mixture was transferred to a well containing $100 \mu \mathrm{l}$ of stop solution ( $1 \mathrm{M} \mathrm{Na}_{2} \mathrm{CO}_{3}, \mathrm{pH} 12$ ) and the change in absorbance at $450 \mathrm{~nm}$ at room temperature was measured in an ELISA plate reader (EAR 340AT, SLT instruments, Austria).

\section{DNA Sequence Analysis}

Direct sequencing was performed on positive samples. The immobilized DNA was incubated with $10 \mu \mathrm{l}$ of $0.1 \mathrm{M} \mathrm{NaOH}$ at room temperature for $10 \mathrm{~min}$ to separate the two DNA strands. The beads were then washed once with $50 \mu$ l of 0.1 $\mathrm{M} \mathrm{NaOH}$ and twice with $50 \mu \mathrm{l}$ of TE buffer $(0.1 \mathrm{M}$ Tris- $\mathrm{HCl}, \mathrm{pH} 7.5,1 \mathrm{~mm}$ EDTA). ${ }^{(18)}$ A robotic workstation described by Hultman et al. ${ }^{(19)}$ was used for the annealing of the sequencing primer and the sequencing reactions. The sequencing reactions were then loaded on an A.L.F. automated laser fluorescent sequencer (Pharmacia LKB, Uppsala, Sweden) and analyzed (data not shown).

\section{RESULTS}

The principle of the technique for detection of $C$. trachomatis from urine, outlined in Figure 1, is based on the primary enrichment of target material through 


\section{IMS}

Immunomagnetic separation

PCR

Polymerase chain reaction

DIANA

Detection of immobilized amplified nucleic acids

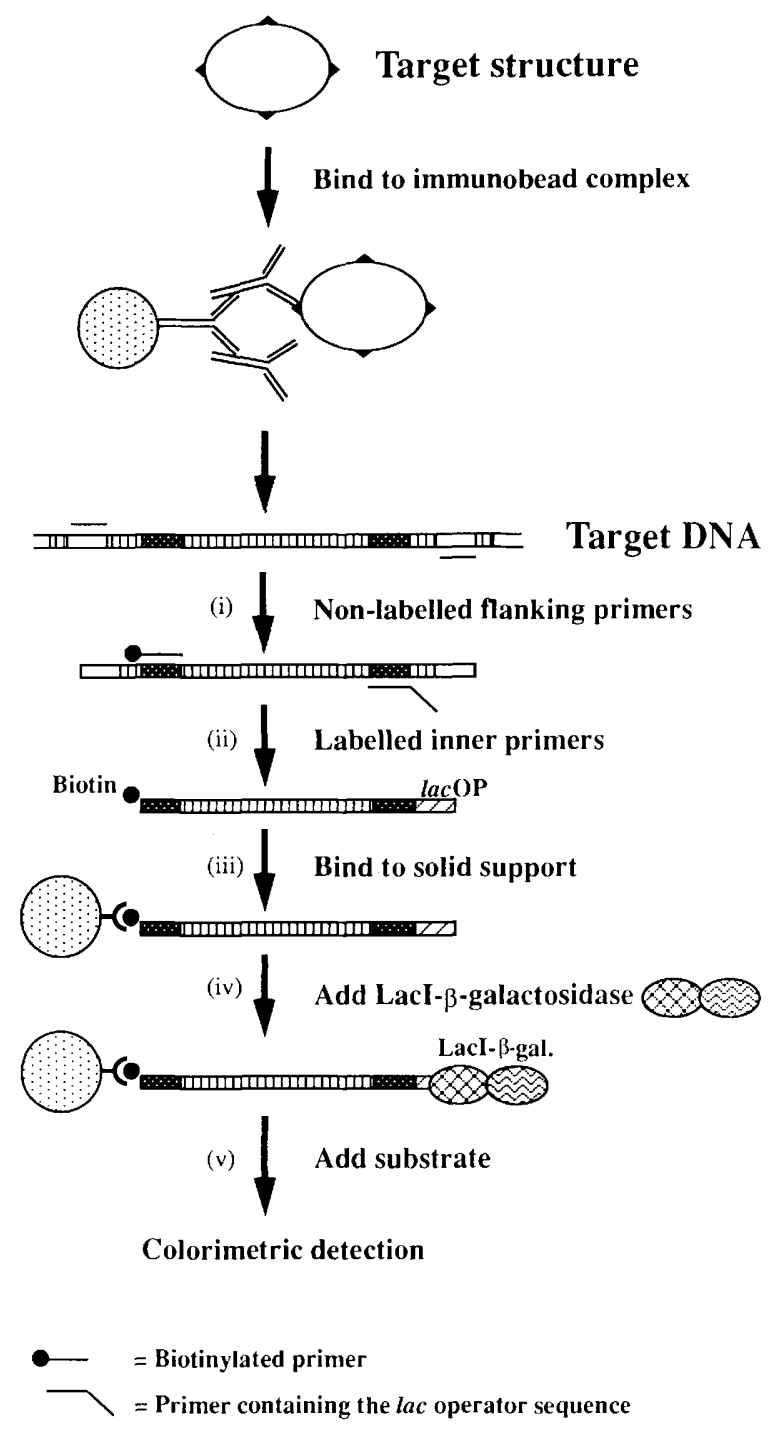

FIGURE 1 The schematic principle of the diagnostic method, containing immunomagnetic separation (IMS), polymerase chain reaction (PCR), and detection of immobilized amplified nucleic acids (DIANA).

immunomagnetic separation (IMS). Elementary bodies, containing genomic $C$. trachomatis DNA, in urine are captured and concentrated using antibody-coated magnetic beads with a primary antibody directed toward C. trachomatis lipopolysaccharides (LPS). The immunocaptured elementary bodies are subsequently used directly in a nested PCR where the inner primer pair consists of one biotinylated primer and one primer containing the Escherichia coli lac operator sequence. Both primer pairs ${ }^{(14)}$ are complementary to sequences in the gene found in all known C. trachomatis sero$\operatorname{vars}^{(16)}$ encoding the outer membrane cysteine-rich protein ( $\mathrm{CrP})$. The detection is performed using a colorimetric method, DIANA. ${ }^{(14)}$ The biotinylated amplified target DNA is immobilized to streptavidin-coated magnetic beads, allowing isolation and subsequent handling of target DNA.

Utilizing the recombinant $E$. coli lac repressor $\beta$-galactosidase reporter fusion protein that binds to the $21-\mathrm{bp}$ E. coli lac operator sequence, one achieves a color reaction for positive samples by adding the chromogenic $\beta$-galactosidase substrate ONPG. The use of magnetic beads for analysis in the DIANA assay makes it possible to perform subsequent solidphase DNA sequencing of positive samples. ${ }^{(14,18)}$ Twenty-seven urine samples were collected and analyzed to evaluate the potential of this method. In parallel, a swab for bacterial cultivation was collected from the same patients. All the samples were collected from suspected cases of $C$. trachomatis, symptomatic (urethritis) men attending a STD clinic. Comparison of the results from cultivation, agarose electrophoresis, and the DIANA assay are shown in Figure 2. The DIANA and the agarose electrophoresis assays both yield $C$. trachomatis-positive results for the same eight samples, whereas the cultivation assay indicates that only five out of these eight are positive. It is not possible to interpret the result for one of the samples (\#3840) by the cultivation possibly because of cytopathologic effect (CPE) caused by infection destroying the McCoy cells used in cultivation. This sample has been detected as positive in the DIANA assay. Two of the samples (\#3621 and 3309) are $1+$ positive by cultivation, corresponding to one to five inclusion-forming units/cell. Both of these samples are positive by the DIANA.

The amplified DNA of the positive samples was sequenced using the solidphase DNA sequencing method. ${ }^{(14,18)}$ The results show a variation of the sequence of the positive samples for the nucleotide position 1072 (Clark et al.) ${ }^{(16)}$ of the CrP gene. Samples 4555, 4543, 3837,3621 , and 3520 were the same as the published sequence, i.e., they have a thymidine residue. Samples numbered 3840,3353 , and 3309 had a cytosine residue at the same position.

This allelic variation did not alter the protein sequence and confirms the presence of the mutation found by Wahlberg et al. ${ }^{(14)}$ In addition, the sequencing revealed that another previously described mutation $^{(14)}$ corresponding to an A-to-G change at position 1190 is present in all positive samples obtained in Sweden. This results in an acidic glutamic acid instead of a basic lysine.

\section{Discussion}

Use of the PCR has facilitated the diagnosis of various bacteria and viruses. ${ }^{(20)}$ Logistical problems, i.e., sample preparation and downstream detection, still exist in the procedures for large-scale diagnosis. Earlier we had described a colorimetric detection system for downstream detection, designated DIANA. In this work a general and integrated system for qualitative diagnosis of $C$. trachomatis from crude urine samples in- 


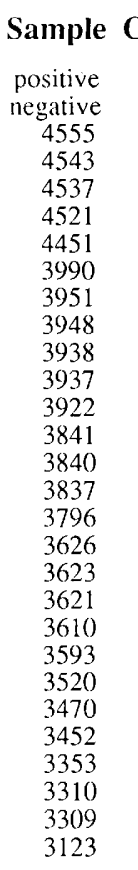

DIANA (Absorbance at $405 \mathrm{~nm}$ )

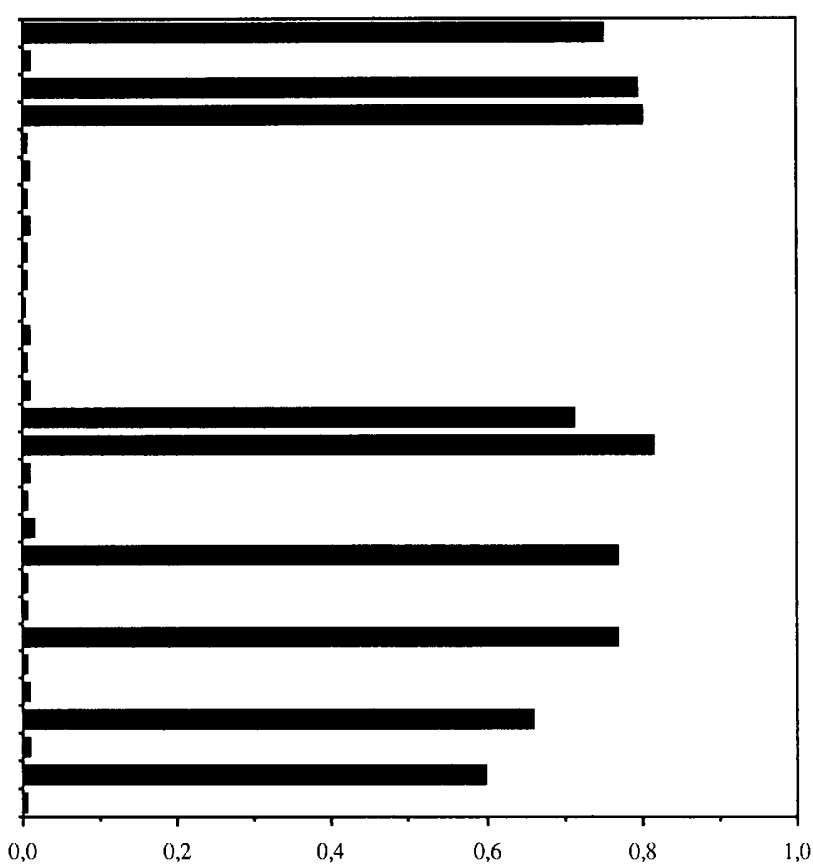

FIGURE 2 Comparison of the results from cultivation, agarose gel electrophoresis and DIANA. See text for details.

volving a novel sample preparation method, PCR, and subsequent colorimetric detection is described. The use of the immunomagnetic separation provides a highly specific tool to capture the target bacteria from crude samples, with the additional advantage that the target can be concentrated and PCR inhibitors eliminated in a simple separation step. The DIANA assay converts the amount of amplified DNA into a colorimetric signal and offers a method to evaluate the results using technology and instruments identical to those used for the conventional ELISA. Traditionally, diagnosis of chlamydial infection has been performed by detection of chlamydial inclusions in tissue culture cells. This cell culture technique requires complicated and costly facilities, making it unavailable in many clinical settings.

Cell culturing is also time consuming and creates problems in specimen handling and transport. A number of factors, especially the use of swabs for sample collection, affect the results of the cultivation, making it unsuitable for mass screening. The technique presented in this paper is performed rapidly using magnetic beads, coated with target-specific antibody, thus eliminating some of the problems in the cultivation technique, i.e., pathogenic effect and the need for viable Chlamydiae. The ability to change buffers, to remove PCR inhibitors, and to optimize the conditions for the amplification might result in a more reproducible test as compared to standard DNA extraction procedures. The specificity of the method, after the immunomagnetic separation step, is further increased by a nested PCR. The inner primer pair is dually labeled to make the amplified material detectable in the DIANA assay and to facilitate direct sequencing of positive samples. The use of magnetic beads in both the IMS and DIANA assay allows for convenient and subsequent handling of the target material. Other material can be envisioned, especially if sequencing is not necessary. In these cases, DIANA can be analyzed using streptavidin-coated microtiter plates instead of magnetic beads with covalently coupled streptavidin (Lundeberg, Hedrum, and Uhlén, unpublished).

The integrated approach described here, consisting of IMS and PCR followed by DIANA, has recently been used also for the detection of Plasmodium falciparum in crude blood samples (Sesood, Hedrum, Lundeberg, and Uhlén, unpublished). The results for the detection of this parasite suggest a sensitivity down to a few parasites per sample. Although the pool of 27 samples described in this work is not sufficient to make firm predictions about sensitivity, the results suggest a higher sensitivity as compared to bacterial cultivation. However, difficulties in quantitating the amount of target organisms in the sample make firm prediction of sensitivity and efficiency difficult.

It is noteworthy that this technique for detection of $C$. trachomatis from urine can be automated relatively simply by using a robotic workstation equipped with a magnetic separator and a thermocycler. ${ }^{(21)}$ In this way, the immunomagnetic separation, PCR, DIANA, and sequencing reactions can all be performed at the same robotic workstation. The automation, the ELISA format (96-well), and the facilitated sample preparation make this technique suitable for largescale screening projects. This system also has the potential for quantifying the initial amount of target molecules as shown earlier for quantification of malaria in clinical samples. ${ }^{(22)}$ Obviously, such quantitative PCR methods could be valuable for many applications, i.e., to follow bacterial and viral titers in patients during therapy.

\section{ACKNOWLEDGMENT}

We are grateful to Prof. Ølsvik, Dr. J. Wahlberg, Dr. P-Å. Nygren, and Dr. T. Dickson for useful discussion. This work has been supported by the Swedish Board for Technical Development and Dynal AS, Oslo, Norway.

\section{REFERENCES}

1. Ward, M.E. 1983. Chlamydial classification, development and structure. Br. Med. Bull. 39: 109-115.

2. Grayston, J.T., C.C. Kuo, L.A. Campbell, and S.P. Wang. 1989. Chlamydia pneumoniae sp. nov. for Chlamydia sp. strain TWAR. Int. J. Syst. Bacteriol. 39: 88-90.

3. Barnes, R.C. 1989. Laboratory diagnosis of human chlamydial infections. Clin. Microbiol. Rev. 2: 119-136.

4. Chernesky, M.A., J.B. Mahony, S. Castriciano, M. Mores, I.O. Stewart, S.J. Landis, W. Seidelman, E.J. Sargeant, and C. Leman. 1986. Detection of Chlamydia trachomatis antigens by enzyme immunoassay and immunofluorescence in genital specimens from symptomatic and asymptomatic men and women. $J$. Infect Dis. 154: 141-148.

5. Hipp, S.S., H. Yangsook, and D. Murphy. 1987. Assessment of enzyme immunoas- 
say and immunofluorescence test for detection of Chlamydia trachomatis. J. Clin. Microbiol. 25: 1938-1943.

6. Kellog, J.A. 1989. Clinical and laboratory considerations of culture vs antigen assays for detection of Chlamydia trachomatis from genital specimens. Arch. Pathol. Lab. Med. 113: 453-460.

7. Lefebvre, J., H. Laperiere, H. Rousseau, and R. Masse. 1988. Comparison of three techniques for detection of Chlamydia trachomatis in endocervical specimens from asymptomatic women. J. Clin. Microbiol. 26: 726-731.

8. Pothier, P. and A. Kazmierczak. 1986. Comparison of cell culture with two different chlamydia tests using immunofluorescence or enzyme-linked immunosorbent assay. Eur. J. Clin. Microbiol. 5: 569572.

9. Schwebke, J.R., A.M. Clark, M.B. Pettinger, P. Nsubga, and W.E. Stamm. 1991. Use of a urine enzyme immunoassay as a diagnostic tool for Chlamydia trachomatis urethritis in men J. Clin. Microbiol. 29: 2446-2449.

10. Østergaard, L., A.G. Lundemose, S. Birkelund, and G. Christiansen. 1990. Age and sex correlation of Chlamydia trachomatis infections evaluated by the culture technique and by an enzyme immunosorbent assay, IDEIA. Eur. J. Obstet. Gyn. Reprod. Biol. 34: 273-281.

11. Saiki, R.K., D.H. Gelfand, S. Stoffel, S.J Scharf, R. Higuchi, G.T. Horn, K.B. Mullis, and H.A. Erlich. 1988. Primer-directed enzymatic amplification of DNA with a thermostable DNA polymerase. Science 239: 487-491.

12. Olsvik, Ø., E. Skjerve, E. Hornes, E. Rimstad, Y. Wasteson, A. Lund, and C. Black. 1991. Magnetic separation and PCR in clinical microbiology. In Magnetic separation techniques applied to cellular and molecular biology (ed. J. Kemshead), pp. 207226. Proceedings of the John Ugelstad Conference, Wordsmiths' Conference Publications, Oxford, UK.

13. Lundeberg, J., J. Wahlberg, M. Holmberg, U. Pettersson, and M. Uhlén. 1990. Rapid colorimetric detection of in vitro amplified DNA sequences. DNA Cell. Biol. 9: 287-292.

14. Wahlberg, J., J. Lundeberg, T. Hultman, and M. Uhlén. 1990. General colorimetric method for DNA diagnostics allowing direct solid-phase genomic sequencing of the positive samples. Proc. Natl. Acad. Sci. 87: 6569-6573.

15. Ripa, K.T. and P-A. Mårdh. 1977. Cultivation of Chlamydia trachomatis on cycloheximide-treated McCoy cells. J. Clin. Microbiol. 6: 328-331.

16. Clark, I.N., M.E. Ward, and P.R. Lambden. 1988. Molecular cloning and sequence analysis of a developmentally regulated cysteine-rich outer membrane pro- tein from Chlamydia trachomatis. Gene 71: 307-314.

17. Lea, T., F. Vartdal, K. Nustad, S. Funderud, A. Berge, T. Ellingsen, R. Schmid, P. Stenstad, and J. Ugelstad. 1988. Monosized, magnetic particles: Their use in separation of cells and subcellular components, and in the study of lymphocyte function in vivo. J. Mol. Recogn 1: 9-18.

18. Hultman, T., S. Ståhl, E. Hornes, and $\mathrm{M}$. Uhlén. 1989. Direct solid phase sequencing of genomic and plasmid DNA using magnetic beads as solid support. Nucleic Acids Res. 17: 4937-4946.

19. Hultman, T., S. Bergh, T. Moks, and M. Uhlén. 1991. Bidirectional solid-phase sequencing of in vitro amplified material. BioTechniques 10: 84-93.

20. Innis, M.A., D.H. Gelfand, J.J. Sninsky, and T.J. White. 1990. Diagnostics and forensics. In PCR protocols, a guide to methods and applications, pp. 325-385, 399-406. Academic Press, San Diego.

21. Wahlberg, J., A. Holmberg, S. Bergh, T. Hultman and M. Uhlén. 1992. Automated magnetic preparation of DNA templates for solid phase sequencing. Electrophoresis (in press).

22. Lundeberg, J., J. Wahlberg, and M. Uhlén. 1991. Rapid colorimetric quantification of PCR-amplified DNA. BioTechniques 10: $68-75$.

Received May 20, 1992; accepted in revised form August 3, 1992. 


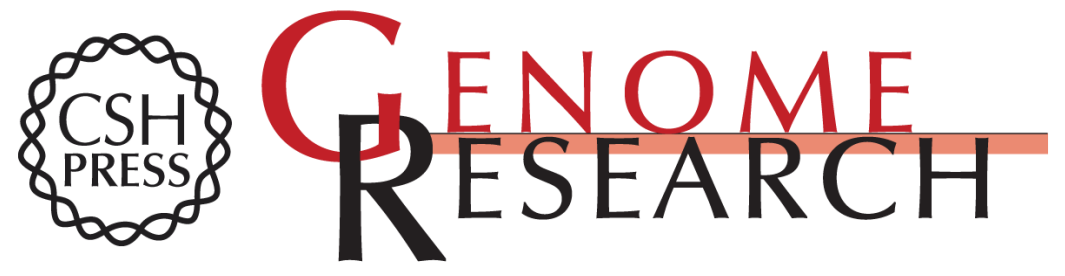

\section{Immunomagnetic recovery of Chlamydia trachomatis from urine with subsequent colorimetric DNA detection.}

A Hedrum, J Lundeberg, C Påhlson, et al.

Genome Res. 1992 2: 167-171

Access the most recent version at doi:10.1101/gr.2.2.167

References This article cites 19 articles, 7 of which can be accessed free at:

http://genome.cshlp.org/content/2/2/167.full.html\#ref-list-1

\section{License}

Email Alerting Receive free email alerts when new articles cite this article - sign up in the box at the Service top right corner of the article or click here.

\section{Affordable, Accurate Sequencing.}

To subscribe to Genome Research go to:

https://genome.cshlp.org/subscriptions 